\title{
ON THE FORELAND MONOCLINES AND FOREDEEPS IN THE MEDITERRANEAN BELTS
}

CARLO DOGLIONI and GOFFREDO MARIOTTI La Sapienza University, Dipartimento di Scienze della Terra, P.le A. Moro 5, Box 11, 00185 Rome, Italy

\begin{abstract}
The foreland monocline is a common feature for all thrust belts or accretionary wedges and related foredeep (Bally, 1983). The foreland geology is often understated in regional studies of orogens, in spite of its crucial role in controlling the thrust belts evolution. The foreland monocline tends to increase its dip toward the interior of the belts (Boyer, 1995), and its subsidence rate controls the development of the trench or the foreland basin, whatever is their origin.

We present new data on the dip of the monocline (Fig. 1) in the frontal part of mainly two orogens, the Alps and the Apennines (Fig. 2), using seismic reflection profiles available in the literature, some industrial data, and regional geologic balanced cross-sections. Where possible, we used the top of the crystalline basement as key bed of reference, or the top of the undeformed Mesozoic, or other layers that could be assumed to parallel the dip of the foreland monocline. Where possible, the dip was computed both in foreland areas, and below the frontal thrusts.

A few more data come from the other thrust belts or accretionary prisms of the Mediterranean area. There is an overall difference between the dip of the Alps and Apennines monoclines, and there is also a strong lateral variation along both arcs. In the Alps, the regional dip varies between $0^{\circ}$ in the remote foreland, to an average of $2-3^{\circ}$ at the front of the thrust belt below the foredeep, to about $5^{\circ}$ beneath the external thrust-sheets within $40 \mathrm{~km}$ from the leading edge of the accretionary wedge. The regional dip of the monocline in the Apennines has an average of 4$5^{\circ}$ at the front of the thrust belt below the foredeep, to about $10^{\circ}$ beneath the external thrustssheets within $40 \mathrm{~km}$ from the leading edge of the accretionary wedge. There are areas where the dip exceeds $20^{\circ}$. The Apennines though topographically lower than the Alps present higher monocline dips and a deeper foredeep.

There are two orders of mean values of the dip of the foreland monocline, the first at the orogen scale (more than $1000 \mathrm{~km}$ wavelength), the second at the regional scale $(100-200 \mathrm{~km}$ wavelength) within the single orogen. Lateral variations in the lithospheric buoyancy due to the inherited Mesozoic stretching may explain the second order variations in foreland dip, but not the first order mean values which seem to be more sensitive to the geographic polarity of the
\end{abstract}


subduction rather than to the lithospheric composition which rather similar in the Alpine and in the central-northern Apennines subduction zones.

Low dips similar to the Alps occur at the front and below the Dinarides, the Mediterranean ridge, the Cyprus arc, the Betics. Steep dips like the Apennines are at the front of the Carpathians, the Rif and segments of the Maghrebides.

High dips of the monocline such as in the Apennines and Carpathians may exceed the critical taper of the wedge, producing an internally dipping accretionary wedge; in fact the envelope to the fold crests may even dip toward the hinterland. This is due to high rates of subsidence which overwhelm the fold uplift rates, generating a negative fold total uplift where the fold subsides while it forms.

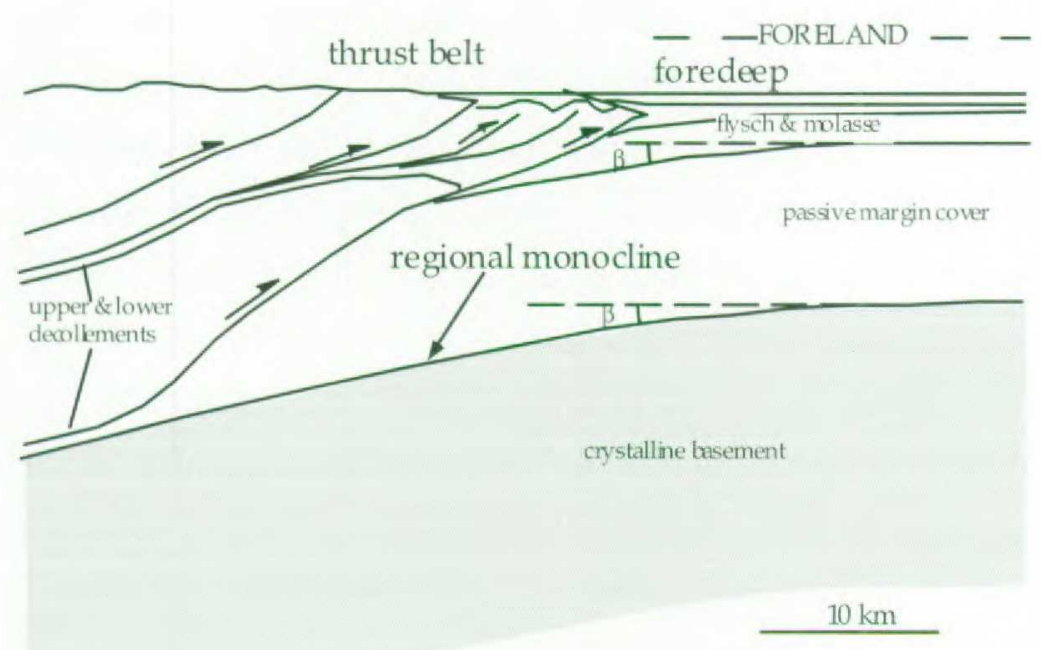

Fig. 1. Idealised front of a thrust belt and the associated regional monocline. The dip $\beta$ generally increases from the foreland to underneath the thrust belt.

The dip variation of the monocline moving along strike of the two belts are generally associated with Permian-Mesozoic inherited horsts (low dip), or basinal areas (steeper dip) which tend to match the salients of the thrust belt front. Within the salients the distance between thrusts ramps increases. Moving along strike the same fold may be either sealed by overlying sedimentation in a faster subsiding foredeep, or subaerially eroded whether it develops respectively on a steep or on a shallow foreland monocline. This may generate opposite oil exploration interests along the same structure.

Thrust-top basins are controlled by the distance among the ramps of the growth folds at the margins of the basin, and therefore they are wider when they develop on top of inherited Mesozoic basins or in areas where the frontal decollement is more advanced due to the presence 
of low friction decollement layers. Different angles of the regional monocline, combined with sediment supply in the foredeep, contribute to control the mechanics of the fold development: the steeper and the deeper the monocline is, the more the fold can be loaded by sediments, and the higher is the lithostatic load acting on the decollement. Moreover, the variable angle of the regional dip generate variable values of the normal and shear stresses induced by the regional maximum horizontal stress acting on the basal decollement which usually parallels the regional dip. Variations along strike of the lithostatic load, combined with the variable dip of the regional monocline, the depth of the decollement on the stratigraphic sequence, the inherited structural and stratigraphic anisotropies and the friction coefficient on the decollement plane, they all control the different propagation and geometries of the basal frontal decollement and the branched thrust ramps.

In the Apennines, the foreland moved and moves 'eastward' due to the retreat of the slab. Whatever is the reason for the slab retreat (i.e., slab pull and/or eastward relative mantle flow, Doglioni, 1994), the rate of retreat is clearly controlled by the composition, thickness, thermal state of the foreland lithosphere. Sharp lateral variations in dip of the foreland monocline indicate areas of different rollback of the subduction hinge, due to pre-existing lateral heterogeneities (e.g. the Mesozoic continent-ocean transition along the Malta escarpment in the eastern Sicilian offshore).

The foreland is often the seat of crustal seismicity, particularly in the Apennines foreland. The differential retreat of the foreland monocline might be responsible for such a seismicity which is usually concentrated along narrow transfer zones, orthogonal to the belt and separating foreland monoclines with different angles.

The variation in dip of the regional monocline across the Malta Escarpment could explain the origin of the Etna volcano which is located in an anomalous position with respect to the Apennines subduction, i.e., on the hinge zone of the slab. The higher dip of the regional foreland monocline in the Ionian oceanic sea $\left(20^{\circ}\right)$ with respect to the eastern Sicily continental lithosphere $\left(6^{\circ}\right)$ implies a larger rollback of the subduction hinge of the Ionian lithosphere toward the southeast with respect to the Hyblean plateau in Sicily where continental subduction is constrained by the shortening in the accretionary wedge. This might explain: i) the PlioPleistocene alkaline magmatism of eastern Sicily (e.g. the Etna volcano); ii) the Late Pliocene to present right lateral transtensional tectonics and seismicity of eastern Sicily. The area of transfer of different dip and rollback occurred along the inherited Mesozoic passive continental margin between Sicily and the oceanic Ionian sea, i.e., the Malta escarpment. The active seismicity along the Malta escarpment is an indirect evidence that the subduction process is still active. 


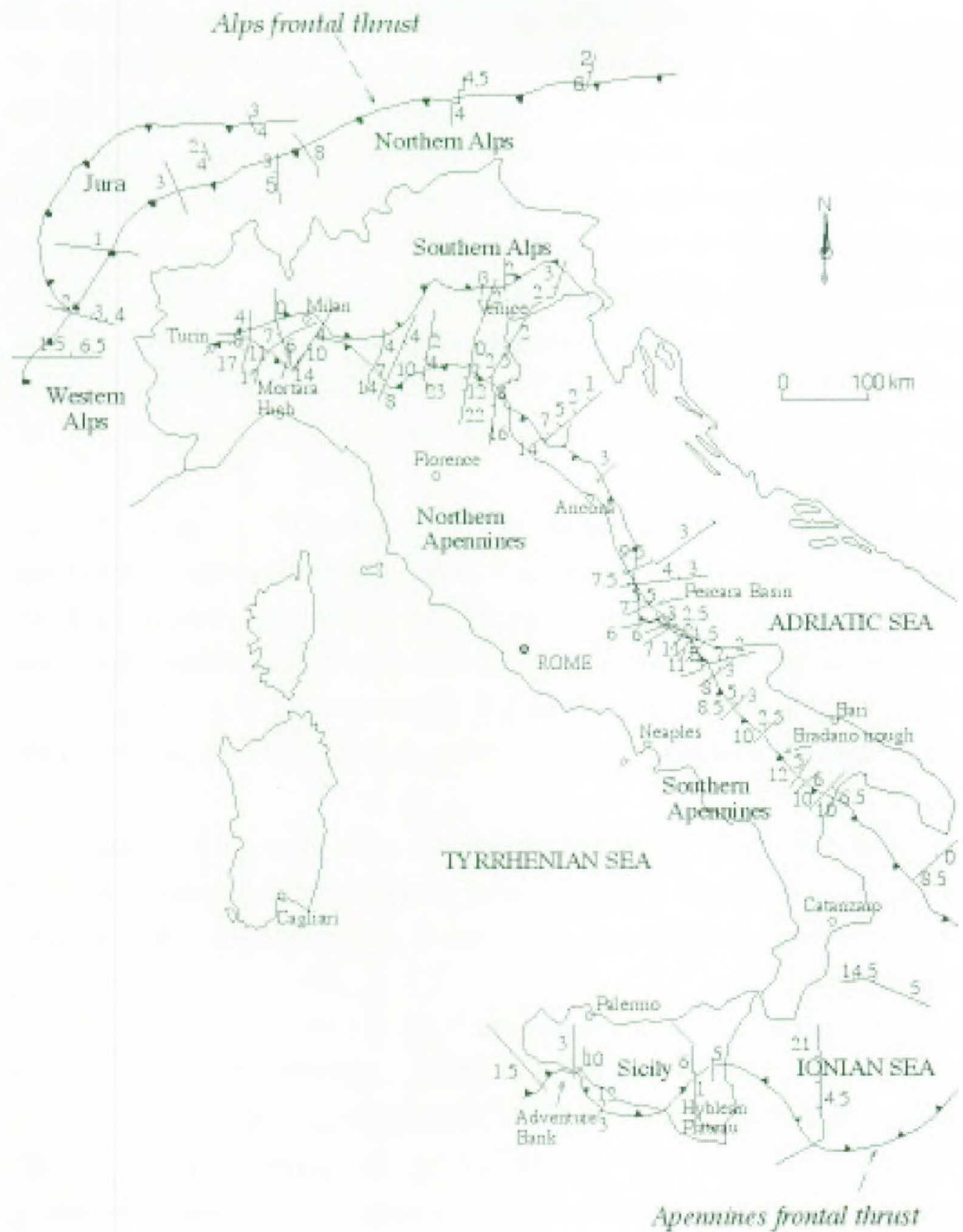

Fig. 2. Dip values of the regional monocline around the Alps and the Apennines. Note the steeper dips of the Apennines foreland.

Bally, A.W. 1983. Seismic expression of structural styles. A picture and work atlas, Am. Ass. Petrol. Geol. Studies in Geology 15, 3vols.

Boyer, S.E. 1995. Sedimentary basin taper as a factor controlling the geometry and advance of thrust belts, Am. J. Sci. 295, 1220-1254.

Doglioni, C. 1994. Foredeeps versus subduction zones, Geology, 22, 271-274. 